\title{
Production of briquettes using coconut and eucalyptus wastes
}

\author{
Eduardo Z. Nunes ${ }^{1}$, Azarias M. de Andrade ${ }^{1} \&$ Ananias F. Dias Júnior ${ }^{2}$ \\ ${ }^{1}$ Universidade Federal Rural do Rio de Janeiro/Departamento de Produtos Florestais. Seropédica, RJ, Brasil. E-mail: ting.71@hotmail.com - ORCID: \\ 0000-0003-2490-1279; azariasmachado@bol.com.br - ORCID: 0000-0002-7246-1696 \\ ${ }^{2}$ Universidade Federal do Espírito Santo/Departamento de Ciências Florestais e da Madeira. Jerônimo Monteiro, ES, Brasil. E-mail: ananias.dias@ufes. \\ br (Corresponding author) - ORCID: 0000-0001-9974-0567
}

\begin{abstract}
This research analyzed the production and characteristics of briquettes composed of residues of Cocos nucifera and Eucalyptus pellita wood. A completely randomized design was used, having seven treatments and five repetitions per treatment. The treatments corresponded to waste percentages of coconut and eucalyptus residues as following: T1: $100 \%$ eucalyptus waste; T2: $20 \%$ coconut waste $+80 \%$ of eucalyptus waste; T3: $40 \%$ coconut waste $+60 \%$ of eucalyptus waste; T4: $50 \%$ coconut waste $+50 \%$ of eucalyptus waste; T5: $60 \%$ coconut waste $+40 \%$ of eucalyptus waste; T6: $80 \%$ coconut waste $+20 \%$ of eucalyptus waste; and, T7: $100 \%$ coconut waste. For the production of briquettes, $0.5 \%$ carboxymethylcellulose (CMC) was used as the binder. The mixtures were compacted under a load of $568 \mathrm{kgf} \mathrm{cm}^{-2}$ for three minutes. After pressing, the briquettes were air-dried to the equilibrium moisture of the environment and, then, analyzed for physical, chemical and energy characteristics. The data were analyzed through analysis of variance, correlations and hierarchical cluster analysis (HCA). The briquettes produced with $100 \%$ of $C$. nucifera residues had the highest equilibrium moisture content, high volatile matter concentrations, and low fixed carbon concentrations. The basic density, the apparent specific mass and the burning rate were not affected by the composition and by the equilibrium moisture of the briquettes.
\end{abstract}

Key words: bioproducts and bioenergy, use of agroforestry residues, compaction and densification of biomass, biofuels

\section{Produção de briquetes usando resíduos de coco e de eucalipto}

RESUMO: Esta pesquisa analisou a produção e as características de briquetes compostos de resíduos de Cocos nucifera e da madeira de Eucalyptus pellita. Utilizou-se o delineamento inteiramente casualizado, com sete tratamentos e cinco repetições. Os tratamentos corresponderam às percentagens de resíduos de coco e de eucalipto, como segue: T1: $100 \%$ de resíduos de eucalipto; T2: $20 \%$ de resíduos de coco $+80 \%$ de resíduos de eucalipto; T3: $40 \%$ de resíduos de coco $+60 \%$ de resíduos de eucalipto; T4: 50\% de resíduos de coco + 50\% de resíduos de eucalipto; T5: 60\% de resíduos de coco + 40\% de resíduos de eucalipto; T6: 80\% de resíduos de coco $+20 \%$ de resíduos de eucalipto e T7: 100\% de resíduos de coco. Para a produção dos briquetes utilizou-se como aglutinante a carboximetilcelulose a 0,5\% (CMC). As misturas foram compactadas, sob uma carga de $568 \mathrm{kgf} \mathrm{cm}^{-2}$, durante três minutos. Após a prensagem, os briquetes foram secos ao ar, até atingirem a umidade de equilíbrio com o ambiente e, em seguida, foram determinadas as características físicas, químicas e energéticas. Os dados foram submetidos à análise de variância, correlações e análise hierárquica de cluster (AHC). Os briquetes produzidos com 100\% de resíduos de C. nucifera, apresentaram as maiores umidades de equilíbrio, elevados teores de materiais voláteis e baixos teores de carbono fixo. A densidade básica, a massa específica aparente e o ritmo de queima não foram afetados pela composição e pela umidade de equilíbrio dos briquetes.

Palavras-chave: bioprodutos e bioenergia, utilização de resíduos agroflorestais, compactação e densificação da biomassa, biocombustíveis 


\section{INTRODUCTION}

Urban wood waste can cause environmental problems and requires effective public policies and planning in any region where its production rate is high. It should be noted that solid wastes, when improperly deposited, can impair the quality and availability of water; contaminate the soil; cause unpleasant odors; and endanger public health (Krook et al., 2006; Bond et al., 2013). One solid residue produced at large scale in Brazil is the shells of coconuts (Cocos nucifera). According to data from Instituto de Geografia e Estatística do Brasil (IBGE, 2015), Brazil has about 300,000 hectares planted with coconut that they can be used for different purposes (Andrade et al., 2004). Other wastes that need attention are those resulting from the industrial processing of Brazilian forest products. It is estimated that, annually, 38.5 million tons of forest residues are generated (Andrade et al., 2017). Wastes from the processing of eucalyptus wood have high calorific value and low ash content and this can increase the energetic properties of coconut compositions.

One of the technical procedures adopted for the reuse of agroforestry residues is briquetting, which deals with the homogenization and densification of lignocellulosic materials and has been presented as an ecologically and economically viable activity (Kaliyan \& Morey, 2010; Dias Júnior et al., 2014; Kelyounssi \& Halim, 2014; Gouvêa et al., 2017). Specifically in relation to the coconut fruits, Andrade et al. (2004) proposed carbonization, while Pimenta et al. (2015) suggested the briquetting of carbonized residues. However, in both situations, heat treatment will be an additional cost to the production of briquettes (Razuan et al., 2011), and in this context, in nature compaction seems to be the least expensive practice.

Solid fuels with a good thermal efficiency can be produced from this process, which is relatively simple to implement. Within this context, this research was aimed at the production and characterization of briquettes of residues of Cocos nucifera combined with residues of Eucalyptus pellita.

\section{Material AND Methods}

Coconut fruits (Cocos nucifera), obtained from the Centro de Tratamento de Resíduos (Ciclus) of the municipality of Seropédica, RJ, Brazil, were used for the production of the briquettes. The eucalyptus (Eucalyptus pellita) wood residues were obtained from five trees, collected at a several-year-old site in the Experimental Area of the Universidade Federal Rural do Rio de Janeiro (22 $44^{\prime} 38^{\prime \prime}$ S; $43^{\circ} 42^{\prime} 27^{\prime \prime}$ W; 26 m of altitude). The residues were ground with a hammer mill and classified by passing through a 3-mm-mesh sieve. Samples were analyzed for moisture content.

A completely randomized design was used, having seven treatments and five repetitions, which corresponded to waste percentages of coconut and eucalyptus residues as following: T1: $100 \%$ eucalyptus waste; T2: $20 \%$ coconut waste $+80 \%$ of eucalyptus waste; T3: $40 \%$ coconut waste $+60 \%$ of eucalyptus waste; T4: $50 \%$ coconut waste $+50 \%$ of eucalyptus waste; T5: $60 \%$ coconut waste $+40 \%$ of eucalyptus waste; T6: $80 \%$ coconut waste $+20 \%$ of eucalyptus waste; and, T7: $100 \%$ coconut waste.
The hypothesis involved in these compositions is that the addition of high-calorific and low-ash wood residues increases the energy characteristics of the abundant residues in several parts of Brazil. The briquetting (compaction) of agroforestry residues was carried out inside a cylindrical metal mold made of stainless steel, using a hydraulic press with a capacity of 15 t. The binder was $0.5 \%$ carboxymethylcellulose (CMC), according to the recommendations of Dias Júnior et al. (2014). The mixture of the residues with $0.5 \%$ CMC were made with the aid of spatulas and ultrasound mixing equipment for homogenization, until it resulted in a uniform material with the consistency that allowed the formation of the briquettes.

During the manufacture of each briquette, the total volume of the mold was filled with the homogenized material, and the mass of this volume of residues corresponded to the respective mass of the briquette. For the pressing of the materials, a load of $568 \mathrm{kgf} \mathrm{cm}^{-2}$, maintained for a period of three minutes, was adopted (Dias Júnior et al., 2014). After pressing, the briquettes were air-dried until they reached equilibrium moisture with the environment.

The bulk densities of coconut and eucalyptus residues were determined under the equilibrium moisture conditions from which they were collected, prior to the briquetting process in accordance with the NBR 6922 standard (ABNT, 2004). The basic density and apparent specific mass of the briquettes were determined following the procedures described by NBR 11941 (ABNT, 2003). Based on the principle of water displacement, the volumes of the briquettes were determined by the hydrostatic method after waterproofing the material with polyethylene film and immersion in water.

The thermal degradation rate of the briquettes was determined by the controlled burning of the material, according to the method performed by Dias Júnior et al. (2014). The briquettes were weighed before and after being submitted to oxidation for the determination of the mass loss. During the five-minute period, the briquettes were subjected to the flame action of a torch fueled by butane gas. The apparatus used was fitted with a burner with working efficiency similar to that of the fan-type models, having the following characteristics: average LPG consumption $=130 \mathrm{~g} \mathrm{~h}^{-1}$; orifice of the injector $=$ $0.25 \mathrm{~mm}$; maximum flame temperature $=975^{\circ} \mathrm{C}$; and distance between the maximum temperature point and the burner end $=15 \mathrm{~mm}$. The output pressure generated was sufficient to prevent the flame from going into the burner.

Immediate chemical analysis of briquettes was performed based on European Stantards DIN. The contents of volatile matter (VM) (DIN, 2001), ash (A) (DIN, 2009) and fixed carbon (FC) (by difference) were determined. The higher calorific value (HCV) was determined using an Ika C200 calorimeter pump, following the standard ASTM E711-87 (ASTM, 2004). The lower calorific value (LCV) was determined with the aid of Eq 1.

$$
\mathrm{LCV}=\frac{(\mathrm{HCV}-25.11 \mathrm{M})}{[(100+\mathrm{M}) 100]}
$$

where:

LCV - lower calorific value, $\mathrm{kcal} \mathrm{kg}^{-1}$; 
$\mathrm{HCV}$ - higher calorific value, $\mathrm{kcal} \mathrm{kg}^{-1}$; and,

M - Moisture, \%.

The data obtained was analyzed for homogeneity variance by Levene and normality by Shapiro Wilk test and analysis of variance. The correlations were tested and, the equations fitted to the variables. These analyses were made at $\mathrm{p} \leq 0.05$.

The multivariate hierarchical cluster analysis (HCA) was applied with the intention of identifying similarity between the treatments studied. Thus, the Manhattan distance was adopted as a measure of proximity, and the method of the average link was used as a technique for grouping similar treatments. The Manhattan metric was chosen based on the fact that it was the least affected by the presence of discrepant values in the samples (Manly, 2008). The distance between clusters was calculated using the average distance between all pairs of objects of the two different clusters. The arithmetic averages of all variables were considered, and they were standardized with mean 0 and variance 1 . All analyses were performed using Minitab $16.0^{\circ}$ software.

\section{Results AND Discussion}

The bulk density values of coconut and eucalyptus residues prior to briquetting ranged from 180 to $222 \mathrm{~kg} \mathrm{~m}^{-3}$, respectively. The average bulk density value of $E$. pellita residues is $23.35 \%$ higher than that of $C$. nucifera residues. Considering the energy utilization of these materials, especially with regard to combustion, such values are considered low and briquetting is a viable alternative for increasing density and better energy efficiency.

Figure 1 presents the equilibrium moisture of the briquettes after being subjected to outdoor drying and stabilization with the environment.

The average values of the equilibrium moisture of the briquettes varied from $13.99 \%$ (T2) to $19.91 \%$ (T7), corresponding to a difference of $42.32 \%$. Despite the absolute oscillations observed between the values, only the T7 treatment was superior to the other treatments. It was observed that the

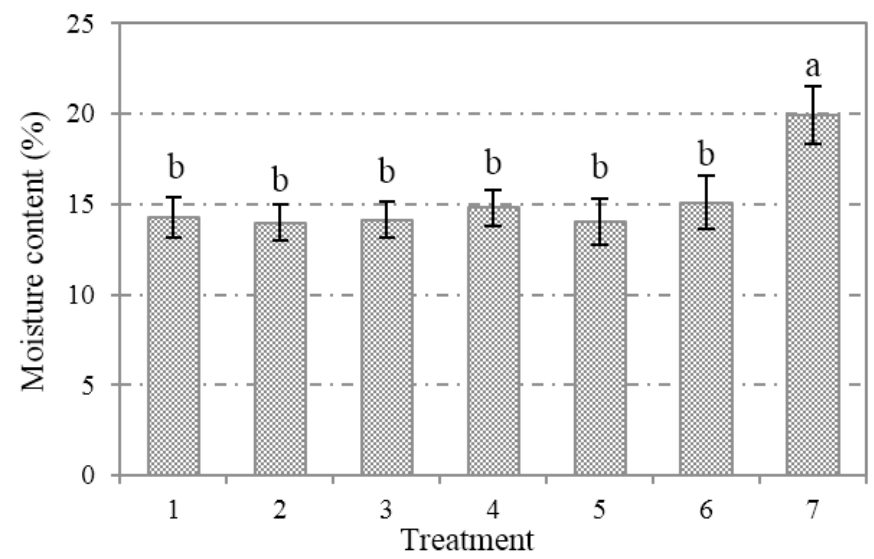

T1: $100 \%$ eucalyptus waste; T2: $20 \%$ coconut waste $+80 \%$ of eucalyptus waste; T3: $40 \%$ coconut waste $+60 \%$ of eucalyptus waste; T $4: 50 \%$ coconut waste $+50 \%$ of eucalyptus waste; T5: $60 \%$ coconut waste $+40 \%$ of eucalyptus waste; T6: $80 \%$ coconut waste $+20 \%$ of eucalyptus waste, and T7: 100\% coconut waste. Means followed by the same letter in the bars do not differ statistically by Tukey test at $\mathrm{p} \leq 0.05$

Figure 1. Equilibrium moisture content of the briquettes produced with mixtures of coconut and eucalyptus briquettes that comprise $100 \%$ coconut wastes had the ability to retain more moisture when exposed to the environment.

According to Andrade et al. (2004), coconut wastes are more hydrophilic than eucalyptus wastes, mainly because they have higher carbohydrate concentration and, consequently, higher amount of free hydroxyl $(\mathrm{OH})$. It may be that, in this case, the formation of hydrogen bonds $(\mathrm{H}-\mathrm{HO})$ has been favored, leading to greater moisture retention. The interaction between the particles, specifically in this treatment, may have generated surfaces more prone to the observed higher moisture. Figure 2 shows the surfaces of the briquettes formed with $100 \%$ eucalyptus residues (T1, Figure 2A) and $100 \%$ coconut residues (T7, Figure 2B).

High moisture is not recommended because it results in crumbling of briquettes during handling (Thek \& Obernberger, 2004; Razuan et al., 2011), in addition to making the briquettes difficult to ignite (Dias Júnior et al., 2015). It can be seen in Figure 2 that the surfaces of the briquettes corresponding to the treatments T1 (100\% of E. pellita wastes) and T7 (100\% of C. nucifera wastes) differ greatly. Coconut fiber bundles appear in large quantities on the surface of the T7 (Figure 2B) treatment briquettes, which may be giving them a more hydrophilic behavior. These fiber bundles, despite having a high affinity for water with a mean hygroscopicity of $13 \%$, also demonstrate a

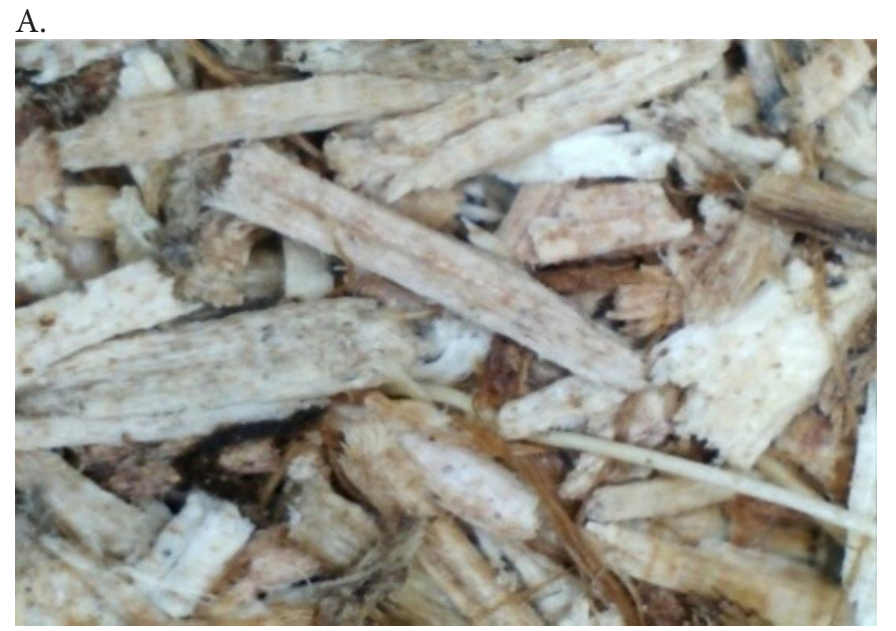

B.

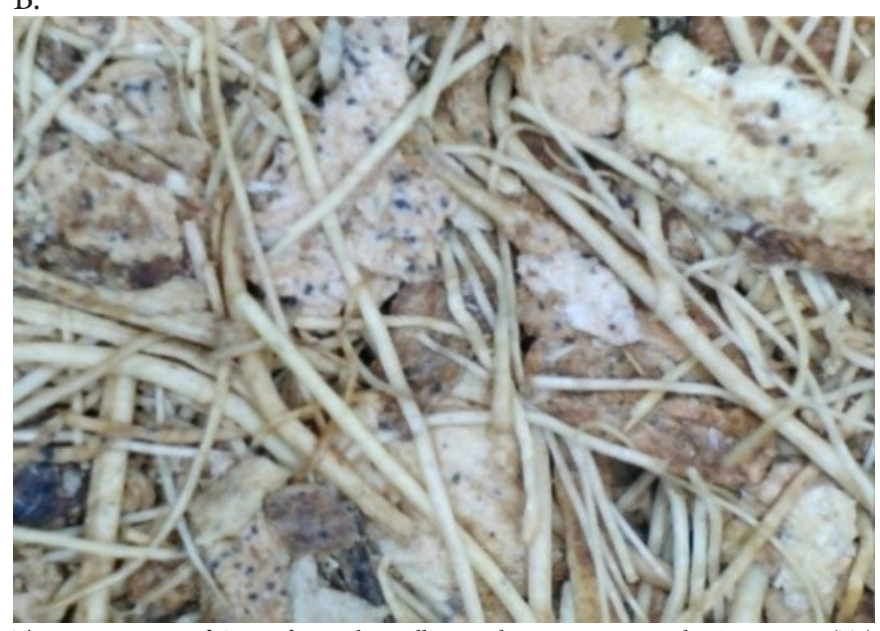

The percentagens of C. nucifera and E. pellita residues are, respectively: $\mathrm{A}=0+100$ (T1) and $\mathrm{B}=100+0(\mathrm{~T} 7)$

Figure 2. Surface of the briquettes formed with $100 \%$ of eucalyptus residues (A) and $100 \%$ of coconut wastes (B), visualized in a digital microscope with $800 \mathrm{X}$ magnification 
great natural resistance to moisture. For Beker et al. (1997), the protein along the cellulose fibers of the biomass are responsible for the bonds and stabilization of the briquettes.

Note, in Figure 3A, that the values of the basic density of the briquettes significantly differ.

Due to the lower average apparent specific mass of coconut wastes, there appears to be a tendency to decrease the basic densities as the content of this waste type increases in the composition of the briquettes. Thus, the briquettes formed with $100 \%$ coconut residues (T7) had the lowest basic density.

In relation to the apparent specific masses of the briquettes, there were no significant differences between the treatments (Figure 3A). However, it should be noted that, from the physical point of view, the results obtained were satisfactory, considering the significant increases observed in relation to the specific masses of the materials before and after the residues were submitted to briquetting, in this way, based on $100 \%$ eucalyptus wastes and $100 \%$ coconut wastes, the apparent specific masses increased 205.98 and $268.88 \%$, respectively, comparing to the values before briquetting. Obidziński (2012) obtained specific mass from 1.14 to $1.34 \mathrm{~g} \mathrm{~cm}^{-3}$ for briquettes produced from potato residues. However, the material morphology and densification conditions may have favored the larger mass allocation per unit volume. According to Husain et al. (2002), one of the ways to raise the density of briquettes is to increase the compaction pressure of the briquettes during production.
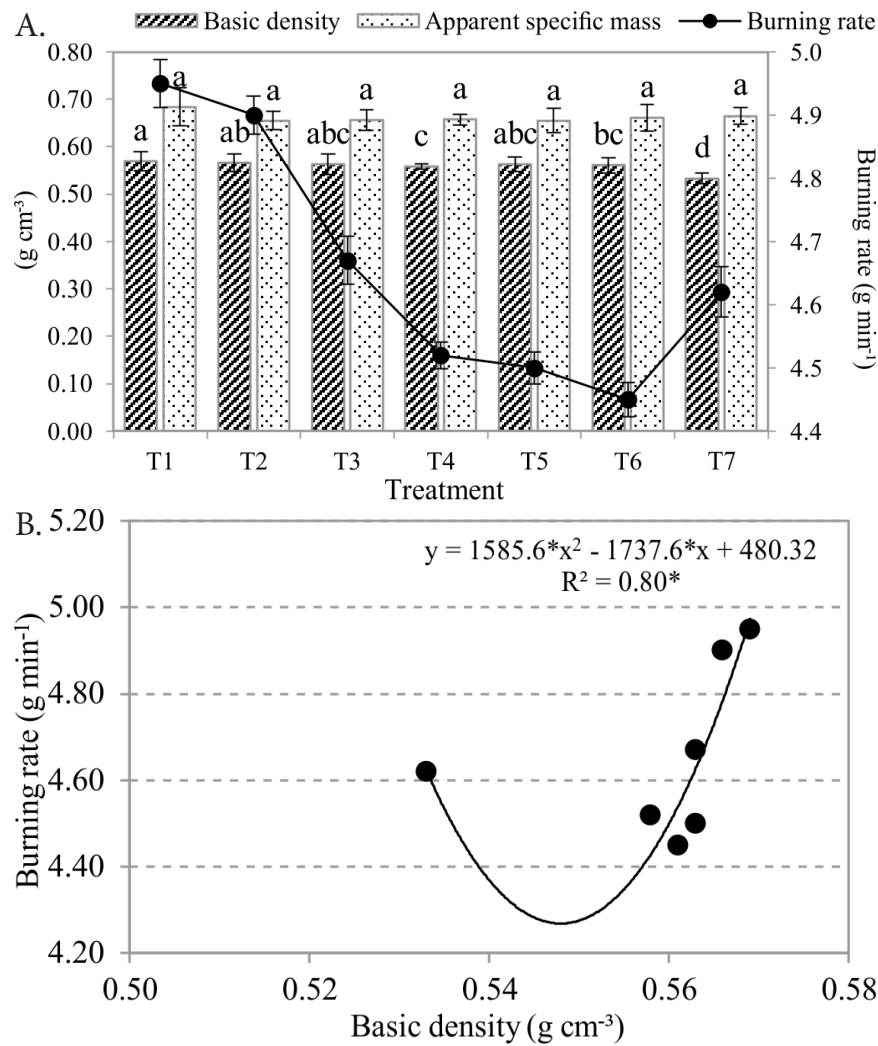

The percentages of C. nucifera and E. pellita residues are respectively: T1: 100\% eucalyptus waste; T2: $20 \%$ coconut waste $+80 \%$ of eucalyptus waste; T3: $40 \%$ coconut waste $+60 \%$ of eucalyptus waste; T4: $50 \%$ coconut waste $+50 \%$ of eucalyptus waste; T5: $60 \%$ coconut waste $+40 \%$ of eucalyptus waste; T6: $80 \%$ coconut waste $+20 \%$ of eucalyptus waste, and T7: $100 \%$ coconut waste. Means followed by the same letter in the bars do not differ statistically by Tukey test at $\mathrm{p} \leq 0.05{ }^{*}$ - Significant at $\mathrm{p} \leq 0.05$ by $\mathrm{F}$ test

Figure 3. Basic density, apparent specific mass and burning rate of briquettes $(\mathrm{A})$, relationship between the burning rate and basic density (B)
The increase in the apparent specific mass, resulting from the transformation of waste into briquettes, is a highly positive factor because it presents a number of advantages, among which the following stand out: generation of a fuel with regular and cleaner dimensions, standardization of moisture and density, greater ease of handling and packaging of fuel, reduction of transport and storage costs, higher concentration of heat energy, greater thermal efficiency during firing, increased possibilities of use, greater ease of commercialization, among other advantages (Quirino et al., 2012; Dias Júnior et al., 2016).

The burning rates of the briquettes (Figure 3A), despite the variations in the compositions and the equilibrium moisture, did not differ significantly. In this research, we obtain burning rate values between 4.45 ( $80 \%$ coconut waste $+20 \%$ of eucalyptus waste, T6) and $4.95 \mathrm{~g} \mathrm{~min}^{-1}$ (100\% eucalyptus waste, T1). For all the analyzed treatments, they remained at acceptable values, suggesting that the thermal deterioration will occur in an adequate time. The values of the burning rates observed in this study were similar to those found by Dias Júnior et al. (2014), evaluating briquettes produced with charcoal fines and bamboo wastes, ranging from 2.0 to $4.5 \mathrm{~g} \mathrm{~min}^{-1}$. In general, it is noted that the increase in the density gave rise to the burning rate of the briquettes (Figure 3B). Thus, the briquettes with the highest densities will possibly degrade thermally faster (Dias Júnior et al., 2014; 2016). The authors observed similar results to those obtained in this study, evaluating briquettes of bamboo wastes and charcoal fines. Probably, the results observed are related to the high volatile contents per unit volume, which favored the ignition and combustion of the briquettes.

In analysis of Table 1, it can be observed that the briquettes had high concentrations of volatile materials.

Values ranged from 68.36 to $83.33 \%$ (e.g. charcoal $=18$ to $25 \%$ ). This can be advantageous when considering direct firing in boiler furnaces and grain dryers, as well as in ceramic kilns, bakeries and pizzerias. This statement is supported by the current technical literature, being linked to the release of large volumes of flammable volatile gases during the burning of fuels with this characteristic and resulting in large amounts of flames (Dias Júnior et al., 2014; Martins et al., 2016).

The ash content was only higher in treatments where coconut residues were present in the briquettes' composition. In this condition, the ash contents ranged from 1.03 to 9.33\% when briquettes with coconut residues were used in proportions ranging from $20 \%$ (T2) to $100 \%$ (T7). According to Sultana et al. (2010), ash contents between 0.5 and $12.5 \%$ are commonly observed after the combustion of pure lignocellulosic biomass. Values above these may indicate that the material is contaminated and constitutes a potential pollutant. According to Trugilho et al. (2005), the ash content is a very variable feature, which depends on several forestry and lignocellulosic biomass factors. Andrade et al. (2004) and Pimenta et al. (2015) reported that $C$. nucifera contains high levels of silica in its outermost layer, the pericarp (bright and greenish), which contributes to the formation of ash after combustion.

The fixed carbon content of the fuel is a variable dependent on and inversely proportional to the volatile and ash contents. 
Table 1. Volatile materials (VM), ash content (AC), fixed carbon (FC), higher calorific value (HCV) and lower calorific value (LCV) of briquettes produced

\begin{tabular}{|c|c|c|c|c|c|}
\hline \multirow{2}{*}{ Treatment } & VM & AC & $\mathrm{FC}$ & $\mathrm{HCV}$ & LCV \\
\hline & \multicolumn{3}{|c|}{$(\%)$} & \multicolumn{2}{|c|}{$\left(\mathrm{kcal} \mathrm{kg}^{-1}\right)$} \\
\hline T1 & $83.33 a \pm 0.89$ & $0.95 c \pm 0.08$ & $16.66 b c \pm 1.12$ & $8033 a \pm 52$ & $6716 a \pm 77$ \\
\hline $\mathrm{T} 2$ & $82.50 \mathrm{a} \pm 1.01$ & $2.66 b c \pm 0.18$ & $14.02 c \pm 0.97$ & $7814 a b \pm 78$ & $6547 a \pm 82$ \\
\hline T3 & $73.33 b c \pm 0.77$ & $9.33 \mathrm{a} \pm 0.98$ & $17.33 b c \pm 1.15$ & $7228 c \pm 50$ & $6074 b \pm 98$ \\
\hline T4 & $76.66 a b \pm 1.34$ & $1.03 c \pm 0.05$ & $22.33 a b \pm 1.65$ & $7964 a \pm 101$ & $6614 a \pm 84$ \\
\hline T5 & $77.10 a b \pm 2.35$ & $2.33 b c \pm 0.07$ & $21.20 b c \pm 1.77$ & $7855 a b \pm 187$ & $6578 a \pm 86$ \\
\hline T6 & $68.36 c \pm 1.89$ & $3.01 b c \pm 0.09$ & $28.66 \mathrm{a} \pm 1.02$ & $7817 a b \pm 178$ & $6462 \mathrm{a} \pm 79$ \\
\hline $\mathrm{T} 7$ & $78.33 a b \pm 1.98$ & $6.66 a b \pm 0.97$ & $15.11 c \pm 0.98$ & 7496 bc \pm 185 & $5834 b \pm 66$ \\
\hline
\end{tabular}

The proportions of residues of C. nucifera and E. pellita are respectively: T1: $100 \%$ eucalyptus waste; T2: $20 \%$ coconut waste $+80 \%$ of eucalyptus waste; T3: $40 \%$ coconut waste $+60 \%$ of eucalyptus waste; T4: $50 \%$ coconut waste $+50 \%$ of eucalyptus waste; T5: $60 \%$ coconut waste $+40 \%$ of eucalyptus waste; T6: $80 \%$ coconut waste $+20 \%$ of eucalyptus waste, and T7: $100 \%$ coconut waste. Means followed by the same letter in the column do not differ statistically by Tukey test at $\mathrm{p} \leq 0.05$; Values after \pm correspond to the mean standard error

It can be reliably said that combinations with the lowest volatile and ash contents result in higher fixed carbon contents and vice versa. Due to the physical, chemical and thermal characteristics acquired by the briquettes, the average values related to the higher calorific values and lower calorific values were shown to be technically acceptable for some bioenergetic uses.

Paula et al. (2011) found higher calorific values for rice husk (3628 kcal kg-1), coffee stems (4334 kcal kg-1), and sugarcane bagasse ( $4065 \mathrm{kcal} \mathrm{kg}^{-1}$ ), as compared to those values observed in this study. Obdzinski (2012), analyzing briquettes from potato residues, obtained values between 3585 and $3824 \mathrm{kcal} \mathrm{kg}^{-1}$. Hence, the results obtained indicate high calorific power for the briquettes produced under the presented conditions, using residues of $C$. nucifera and E. pellita.

Figure 4 shows the dendrogram obtained by cluster analysis.

Considering the cutoff point on a distance scale (Manly, 2008), the formation of three clusters was observed with $60 \%$ equivalence for total similarity. The first cluster was formed by the T1, T2, T4 and T5 treatments, the second cluster was formed by the T3 treatment and the third cluster consisted of the T7 treatment. Cluster I, together with cluster II, were the most suitable for energy uses. It can be observed in Table 2 that the treatments belonging to cluster I showed lower moisture, higher basic densities and apparent specific masses, high heat powers and low ash content. Such factors are paramount when the purpose is energy use.

The high moisture content, which is linked to the low density and also observed in cluster III, can negatively interfere

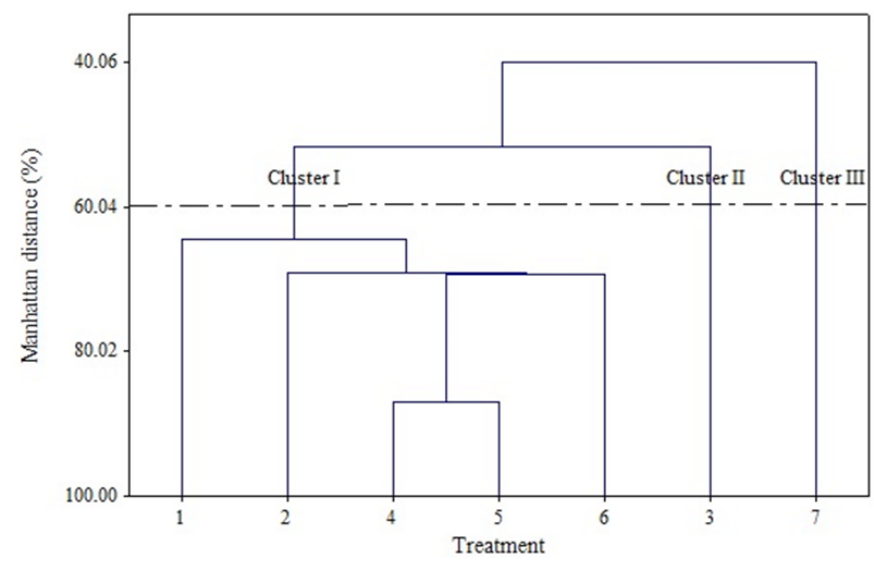

The percentages of residues of C. nucifera and E. pellita are respectively: T1: $100 \%$ eucalyptus waste; T2: $20 \%$ coconut waste $+80 \%$ of eucalyptus waste; T3: $40 \%$ coconut waste $+60 \%$ of eucalyptus waste; T4: $50 \%$ coconut waste $+50 \%$ of eucalyptus waste; T5: $60 \%$ coconut waste $+40 \%$ of eucalyptus waste; T6: $80 \%$ coconut waste $+20 \%$ of eucalyptus waste, and T7: $100 \%$ coconut waste

Figure 4. Hierarchical cluster analysis of the analyzed treatments
Table 2. Average values of the variables for the clusters established by the hierarchical cluster analysis (HCA)

\begin{tabular}{lccc}
\hline \multicolumn{1}{c}{ Variable } & Cluster I & Cluster II & Cluster III \\
\hline Moisture content (\%) & 14.44 & 14.14 & 19.91 \\
Basic density $\left(\mathrm{g} \mathrm{cm}^{-3}\right)$ & 0.563 & 0.563 & 0.533 \\
Apparent specific mass $\left(\mathrm{g} \mathrm{cm}^{-3}\right)$ & 0.662 & 0.656 & 0.665 \\
Burning rate $\left(\mathrm{g} \mathrm{cm}^{-1}\right)$ & 4.66 & 4.67 & 4.62 \\
Volatile materials (\%) & 77.67 & 73.33 & 78.33 \\
Ash contents (\%) & 1.81 & 9.33 & 6.66 \\
Fixed carbon (\%) & 20.53 & 17.33 & 15.01 \\
\hline Higher calorific value $\left(\mathrm{kcal} \mathrm{kg}^{-1}\right)$ & 7896 & 7228 & 7496 \\
\hline Lower calorific value $\left(\mathrm{kcal} \mathrm{kg}^{-1}\right)$ & 6583 & 6074 & 5834 \\
\hline
\end{tabular}

in the volumetric calorific value $\left(\mathrm{kcal} \mathrm{m}^{-3}\right)$, i.e. the amount of energy per unit volume of combustible material (Protásio et al., 2013). Cluster III may be classified as an intermediate for bioenergetic use depending on ash content and calorific value. The higher levels of volatiles observed for this cluster result in the ease of ignition and the generation of flames of the fuel during burning (Dias Júnior et al., 2014; 2015).

\section{Conclusions}

1. The briquettes produced with $100 \%$ coconut wastes, have higher moisture content at equilibrium in the environment, high volatile matter concentration and low fixed carbon concentration.

2. Basic density, apparent specific mass and burning rate are not significantly affected by the waste mixtures briquettes.

3. The Cluster I formed by T1: $100 \%$ eucalyptus waste, T2: $20 \%$ coconut waste $+80 \%$ of eucalyptus waste, T4: $50 \%$ coconut waste $+50 \%$ of eucalyptus waste, T5: $60 \%$ coconut waste $+40 \%$ of eucalyptus waste, is the most suitable for energy purposes and for the production of biofuels.

\section{Literature Cited}

ABNT - Associação Brasileira de Normas Técnicas. ABNT NBR 11941: Madeira - determinação da densidade básica. Rio de Janeiro: ABNT, 2003. 5p.

ABNT - Associação Brasileira de Normas Técnicas. ABNT NBR 6922: 1981: Carvão vegetal - ensaios físicos determinação da massa específica (densidade à granel). Rio de Janeiro: ABNT, 2004. 25p. Andrade, A. M. de; Passos, P. R. de A.; Marques, L. G. da C.; Oliveira, L. B.; Vidaurre, G. B.; Rocha, J. das D. de S. Pirólise de resíduos do coco-da-baía (Cocos nucifera Linn) e análise do carvão vegetal. Revista Árvore, v.28, p.707-714, 2004. https://doi.org/10.1590/ S0100-67622004000500010 
Andrade, C. R.; Brito, J. O.; Dias Júnior, A. F.; Lana, A. Q. Changes caused by torrefaction on urban wooden waste. Scientia Forestalis, v.45, p.275-284, 2017. https://doi.org/10.18671/scifor.v45n114.04

ASTM - American Society for Testing Materials. ASTM E711-87: Standard test method for gross calorific value of refuse-derived fuel by the bomb calorimeter. Philadelphia: ASTM, 2004. 8p.

Beker, U. G. Briquetting of Asfin-Elbistan lignite of Tukey using different waste materials. Fuel Processing Technology, v.137, p.211-216, 1997. https://doi.org/10.1016/S0378-3820(96)01081-8

Bond, T. C.; Doherty, S. J.; Fahey, D. W.; Forster, P. M.; Berntsen, T.; Deangelo, B. J.; Flanner, M. G.; Ghan, S.; Kärcher, B.; Koch, D.; Kinne, S.; Kondo, Y.; Quinn, P. K.; Sarofim, M. C.; Schultz, M. G.; Schulz, M.; Venkataraman, C.; Zhang, H.; Zhang, S.; Bellouin, N.; Guttikunda, S. K.; Hopke, P. K.; Jacobson, M. Z.; Kaiser, J. W.; Klimont, Z.; Lohmann, U.; Schwarz, J. P.; Shindell, D.; Storelvmo, T.; Warren, S. G.; Zender, C. S. Bounding the role of black carbon in the climate system: A scientific assessment. Journal of Geophysical Research: Atmospheres, v.11, p.5380-5552, 2013. https://doi.org/10.1002/jgrd.50171

Dias Júnior, A. F.; Andrade, A. M. de Carvalho, A. M. de; Benicio, E. L; Brito, J. O. Produção de briquetes de moinha de carvão vegetal e resíduos lignocelulósicos visando uso bioenergético. Scientia Forestalis, v.44, p.453-462, 2016. https://doi.org/10.18671/scifor. $\mathrm{v} 44 \mathrm{n} 110.18$

Dias Júnior, A. F.; Andrade, A. M. de; Costa Júnior, D. S. da. Caracterização de briquetes produzidos com resíduos agroflorestais. Pesquisa Florestal Brasileira, v.34, p.225-234, 2014. https://doi.org/10.4336/2014.pfb.34.79.613

Dias Júnior, A. F.; Brito, J. O.; Andrade, C. R. Granulometric influence on the combustion of charcoal for barbecue. Revista Árvore, v.39, p.1127-1133, 2015. https://doi.org/10.1590/010067622015000600016

DIN - Deutsches Institut Für Normung. DIN EN 51720: Testing of solid fuels - Determination of volatile matter content. Berlin: DIN, 2001. 1p.

DIN - Deutsches Institut Für Normung. DIN EN 14775: Determination of ash content. Berlim: DIN, 2009. 12p.

Gouvêa, A. de F. G.; Carvalho, A. M. L.; Silva, C. M.; Carneiro, A. de C. O.; Trugilho, P. F.; Freita, F. P. de; Valadares, L. B.; Gomes, C. M.; Costa, E. B. Estudo da adição da lignina kraft nas propriedades mecânicas dos briquetes de resíduos da indústria moveleira. Ciência Florestal, v.27, p.1029-1036, 2017. https:// doi.org/10.5902/1980509828678

Husain, Z.; Zainac, Z.; Abdullah, Z. Briquetting of palm fibre and shell from the processing of palm nuts to palm oil. Biomass and Bioenergy, v.22, p.505-509, 2002. https://doi.org/10.1016/ S0961-9534(02)00022-3

IBGE - Instituto Brasileiro de Geografia e Estatística. Banco de dados agregados- Produção Agrícola dos Municípios. 2015. Available at: <http://www.sidra.ibge.gov.br/bda/tabela/listabl. asp? $c=1613 \& z=p \& o=20>$ Access at: May 2018.

Kaliyan, N.; Morey, R. V. Natural binders and solid bridge type binding mechanisms in briquettes and pellets made from corn stover and switchgrass. Bioresource Technology, v.101, p.1082-1090, 2010. https://doi.org/10.1016/j.biortech.2009.08.064
Kelyounssi, K.; Halim, M. An investigation on the texture and microstructure of carbonized charcoals produced by two-step pyrolysis. Journal of Analytical and Applied Pyrolysis, v.3, p.258265, 2014. https://doi.org/10.1016/j.jaap.2014.06.003

Krook, J.; Mârtensson, A.; Eklund, M. Sources of heavy metal contamination in Swedish wood waste used for combustion. Waste Management, v.26, p.158-166, 2006. https://doi.org/10.1016/j. wasman.2005.07.017

Manly, B. J. F. Métodos estatísticos multivariados: Uma introdução. 3.ed. Porto Alegre: Bookman, 2008. 229p.

Martins, M. P.; Benicio, E. L.; Dias Júnior, A. F.; Almeida, R. B. de; Carvalho, A. M. de; Yamaji, F. M. Produção e avaliação de briquetes de finos de carvão vegetal compactados com resíduo celulósico proveniente da indústria de papel e celulose. Revista Árvore, v.40, p.173-180, 2016. https://doi.org/10.1590/010067622016000100019

Obdzinski, S. Analysis of usability of potato pulp as solid fuel. Fuel Processing Technology, v.94, p.67-74, 2012. https://doi. org/10.1016/j.fuproc.2011.10.012

Paula, L. E. de R. e; Trugilho, P. F.; Rezende, R. N.; Assis, C. O. de; Baliza, A. E. R. Produção e avaliação de briquetes lignocelulósicos. Pesquisa Florestal Brasileira, v.31, p.103-112, 2011. https://doi. org/10.4336/2011.pfb.31.66.103

Pimenta, A. S.; Santos, R. C. dos; Carneiro, A. C. de O.; Castro, R. V. O. Utilização de resíduos de coco (Cocos nucifera) carbonizado para a produção de briquetes. Ciência Florestal, v.25, p.137-144, 2015. https://doi.org/10.5902/1980509817471

Protásio, T. de P.; Bufalino, L.; Guimarães Junior, M.; Tonoli, G. H. D.; Trugilho, P. F. Técnicas multivariadas aplicadas à avaliação de resíduos lignocelulósicos para a produção de bioenergia. Ciência Florestal, v.23, p.771-781, 2013. https:/doi. org/10.5902/1980509812361

Razuan, R.; Finney, K. N.; Chen, Q.; Sharifi, V. N.; Swithenbank, J. Pelletised fuel production from palm kernel cake. Fuel Processing Technology, v.92, p.609-615, 2011. https://doi.org/10.1016/j. fuproc.2010.11.018

Sultana, A.; Kumar, A.; Harfield, D. Development of agri-pellet production cost and optimum size. Bioresource Technology, v.101, p.5609-5621, 2010. https://doi.org/10.1016/j. biortech.2010.02.011

Quirino, W. F.; Pinha, I. V. de O.; Moreira, A. C. de O.; Souza, F. de; Tomazello Filho, M. Densitometria de raios-x na análise da qualidade de briquetes de resíduos de madeira. Scientia Forestalis, v.40, p.525-536, 2012.

Thek, G.; Obernberger, I. Wood pellet production costs under Austrian and in comparison to Swedish framework conditions. Biomass and Bioenergy, v.27, p.671-693, 2004. https://doi. org/10.1016/j.biombioe.2003.07.007

Trugilho, P. F.; Silva, J. R. M. da; Mori, F. A.; Lima, J. T.; Mendes, L. M.; Mendes, L. F. de B. Rendimentos e características do carvão vegetal em função da posição radial de amostragem em clones de Eucalyptus. Cerne, v.11, p.178-186, 2005. 